\title{
MOLAPE SARONDE DAN MOTIDI DALAM BINGKAI ADAT DAN AGAMA DI GORONTALO
}

\section{MOLAPE SARONDE AND MOTIDI IN THE FRAME OF CUSTOM AND RELIGION IN GORONTALO}

\author{
Syarifuddin \\ Balai Penelitian dan Pengembangan Agama Makassar \\ Jl. A.P.Pettarani No.72 Makassar \\ Email: syarifuddinamir84@yahoo.com
}

Naskah diterima tanggal 8 Maret 2016. Naskah direvisi tanggal 23 Maret 2016. Naskah diterima tanggal 3 Juni 2016.

\begin{abstract}
Abstrak
Sejak Sultan Amai menganut Agama Islam sekaligus menjadikannya sebagai agama resmi kerajaan di Gorontalo, terjadi proses islamisasi adat dan tradisi pada masyarakat Gorontalo.Akhirnya, nilai-nilai lokal yang berkembang di Gorontalo bermuara dari nilai-nilai Islam. Dengan falsafah "Adati Hulo-Huloqa To Saraqa, Saraqa Hulo-Huloqa To Kuruqani” (Adat Bersendi Syara', Syara’ Bersendi Alquran), nilai Islam selalu mewarnai seluruh upacara adat tak terkecuali upacara adat pernikahan. Molape Saronde dan Motidi sebagai bagian dari upacara adat pernikahan pada tahapMopotilantahu (mempertunangkan), tak lepas lepas dari nilai Islam.Tari Molape Saronde (ditarikan oleh pengantin laki-laki) dan Motidi (ditarikan oleh pengantin perempuan) diadakan pada malam hariacara pernikahan dirangkaikan dengan acara khatam Alquran bagi pengantin perempuan. Menjunjung tinggi adat serta berpegang tegang etika islami menjadi tema sentral dalam Tradisi Molape Saronde dan Motidi. Tradisi ini juga sekaligus menjadi nasihat bagi kedua calon mempelai sebagai bekal dalam menghadapi kehidupan rumah tangga yang penuh tantangan.
\end{abstract}

Kata Kunci: adat, molape saronde, motidi, syair.

\begin{abstract}
Since Sultan Amai embraced Islam at the same time making he made it as the official religion of the kingdom in Gorontalo, a process of Islamization customs and traditions of the people of Gorontalo. Finally, the local values that developed in Gorontalo were not mixed with the Islamic values. With the philosophy "Traditional Hulo-Huloqa To Saraqa, Saraqa Hulo-Huloqa To Kuruqani" (custom based on Syara ', Syara' based on Quran), the Islamic values always paint the entire traditional wedding ceremonies, and there are no exception. Molape Saronde and Motidi as part of the wedding ceremonies on stage Mopotilantahu (betrothed), could not be separated off from the values of Islam. Saronde Molape dance (danced by recite the groom) and Motidi (danced by the bride) was held in the evening. In the wedding party, there is a ceremony of reciting al-Quran held for the bride as the graduation day that she has a ready finished her study of reading the al-Quran. Both of bride and groom should hold the custom, and to be taught the Islamic ethics as the central theme in the tradition of Molape Saronde and Motidi
\end{abstract}

Keywords: custom, molape saronde, motidi, poetry,bride

\section{PENDAHULUAN}

G orontalo sebuah daerah yang berbudaya yang sangat teguh memegang adat dan tradisi penduhulunya. Nilai-nilai lokal yang berkembang di Gorontalo tak lepas dari peran kerajaan tradisional yang pernah berkembang di wilayah itu. Dengan falsafah "Adati Hulo-Huloqa To Saraqa, Saraqa Hulo-Huloqa To Kuruqani”" (Adat Bersendi Syara', Syara' Bersendi Alquran), nilai lokalitas yang berkembang bermuara dari nilai-nilai Islam sebagai agama resmi kerajaan. Konsep ini sendiri tidak muncul sendirinya tetapi mengalami transformasisejakpemerintahanSultan Amaisebagai Raja pertama yang masuk Islamsehingga melahirkan rumusan "syarak bertumpu pada adat". Selanjutnya pemerintahan Motolodulakikimelahirkan rumusan "adat bersendikan syarak, syarak bersendikan adat". Hingga akhirnya Eyato menyempurnakannya dengan rumusan "Adati Hulo-Huloqa To Saraqa, 
Saraqa Hulo-Huloqa To Kuruqani” yang berarti Adat Bersendi Syara', Syara' Bersendi Alquran (Polontalo, 2003: 157). Konsep yang dikembangkan oleh Raja Eyato inilah yang mewarnai aspek kehidupan masyarakat Gorontalo yang tergambar dalam beberapa aspek seperti, tradisi kelahiran, pernikahan, penyambutan tamu, penobatan dan kematian (Hasanuddin dan Basri Amin, 2012: 2527).

Setelah Islam masuk ke Gorontalo dan menjadi agama resmi, secara perlahan terjadi islamisasi peradatan. Islamisasi peradatan ini dapat dilihat dari masuknya simbol Islam ke dalam peradatan, pengunaan ayat-ayat suci Alquran dan Hadis ke dalam wacana adat, pelaksana adat terdiri atas tokoh adat dan tokoh agama serta tempat pelaksanaan sering dikaitkan dengan tempat ibadah atau masjid (Tuloli, 2003: 71).

Pernikahan adalah salah satu siklus hidup manusia. Tujuannya yaitu untuk mewujudkan keluarga bahagia, sakinah, mawaddah dan penuh kasih sayang. Untuk itu diperlukan media pembelajaran bagi seorang yang hendak melangkah ke jenjang pernikahan sebagai bekal dalam mengarungi kehidupan baru yang penuh tantangan. Adat pernikahan masyarakat Gorontalo memiliki tahapan yang sangat kental dengan nilai-nilai lokal yang bersandingkan dengan ajaran-ajaran agama sebagai pengajaran.

Berdasarkan latar belakang maka yang menjadi permasalah pada penelitian ini yaitu: Bagaimana pelaksanaan tradisi Molape Saronde dan Motidi di Gorontalo dalam adat masyarakat Gorontalo? Bagaimana tema wacana syair padapelaksanaan tradisi Molape Saronde dan Motidi di Gorontalo?. Tujuan penelitian ini untuk mendeskripsikan pelaksanaan tradisi Molape Saronde dan Motidi di Gorontalo dalam adat masyarakat Gorontalo, mendeskripsikan tema wacana syair padapelaksanaan tradisi Molape Saronde dan Motidi di Gorontalo.

\section{Kajian Pustaka}

Fatmah Umar dalam hasil penelitiannya tentang Ideologi Tuja'i dalam tahap pernikahan di Gorontalo mengemukakan banyak dimensi adat dan keagamaan. Kajian ini merupakan kajian analisis wacana kritis dengan menemukan beberapa tema wacana dalam tahap Motolobolango yaitu; ketauhidan, kepemimpinan, melewati kesusahan, kesungguhan dan ksatria, tawadhu, kesatuan dan persatuan, kehadiran, demokrasi, kesepakatan awal, kearifan dan kebijaksanaan, ketangguhan, kegelisahan, kesiapan awal, kejujuran, kecekatan dan ketelitian, kepercayaan pada takdir, kewaspadaan, kepercayaan diri, kehormatan diri, keikhlasan, keraguan, kesaksian dan kedisiplinan. (Umar, tth: 133). Selanjutnya ia mengemukan tema khusus pada momanato yaitu: penjagaan dan pengamalan adat istiadat, pemenuhan hak dan kewajiban, pengendalian diri, pemerataan, serta penghormatan dan penghargaan (Umar, tth: 175).

Kajian Fatmah AR. Umar tersebut di atas, hanya terfokus pada dua tahap yaitu motolobolango dan momanato. Oleh karena itu, kajian ini terfokus pada salah satu tahapan yang lain yaitu tahapan mopotilantahu (mempetunangkan) yang diadakan pada malam hari acara akad nikah. Pada tahap ini, biasanya diadakan tradisi menamatkan Quran (bagi pengantin perempuan), Molape Saronde dan Motidi. Seperti halnya tahapan yang lain, diasumsikan pula bahwa pada tahapan mopotilantahu (mempetunangkan) sangat sarat dengan dimensi adat dan keagamaan sebagai refleksi dari falsafah Gorontalo yang bersendikan adat dan agama.

\section{METODE PENELITIAN}

Penelitian ini menggunakan metode kualitatif dengan pola analisis wacana kritis serta menjadikan wacana syair dalam tradisi molape saronde dan motidi sebagai objek kajian.Pendekatan penelitian ini terfokus pada peran kekuasaan (ideologi) dalam hal ini falsafah Adati Hulo-Huloqa To Saraqa, Saraqa Hulo-Huloqa To Kuruqani serta bagaimana kekuasaan itu diproduksi, dibuat dan dilegitimasi oleh masyarakat. Teori yang digunakan dalam kajian ini yaitu teori analisis wacana. Dalam hal ini (Eriyanto, 2011: 11), wacana yang muncul dalam bentuk teks, percakapan, atau apapun tidak dipandang sebagai sesuatu yang alamiah, wajar, dan netral.Disamping itu juga, ideologi sebagai konsep sentral dalam hal ini teks, percakapan, dan lainnya adalah bentuk dari praktik ideologi atau pencerminan ideologi tertentu. Teori klasik tentang ideologi mengatakan bahwa ideologi dibangun oleh kelompok yang dominan dengan tujuan untuk mereproduksi dan melegitimasi dominasi mereka (Eriyanto, 2011: 13). Teknik pengumpulan data yang digunakan yaitu berupa wawancara, studi pustaka dan dokumen, serta perekaman dan pencatatan pada acara tradisi lokal yang diteliti. 


\section{PEMBAHASAN}

\section{Agama dan Budaya Masyarakat Gorontalo}

Gorontalo merupakan daerah yang dikenal sebagai daerah religius dengan posisi agama Islam sebagai agama mayoritas yang sangat mempengaruhi prilaku kehidupan masyarakat Gorontalo. Berdasarkan data statistik tahun 2013 penduduk Penduduk Gorontalo beragama Islam 1.007.056 (96.81\%), Kristen 21.987 (2.11\%), Katolik 7.348 (0.71\%), Hindu 2.870 (0.28\%), Budha 903 (0.09\%). Sementara data jumlah rumah ibadah di Gorontalo yaitu: Masjid/Mushallah 1923 buah, Gereja Kristen 132 buah, Gereja Katolik 10 buah, Pura 32 buah, dan Vihara 4 buah (Kanwil Kementerian Agama Gorontalo, 2013). Di samping dikenal sebagai daerah religius, Gorontalo juga dikenal sebagai wilayah yang sangat menjunjung adat istiadat dan mengejawatahkan dalam falsafahnya. Secara umum, Upacara Adat Yang terbagi dalam 5 bahagian (Daulima, 2003: 199-200).:

1. Adat Istiadat pada kelahiran dengan tahapan sebagai berikut: Molonthalo, (acara pernyataan dari pihak suami bahwa kehamilan pertama adalah harapan yang terpenuhi akan kelanjutan turunan perkawinan yang sah), Molobunga yiliyala, (acara menguburkan plesenta atau tembuni bayi yag dilahirkan, Mobangu, Mokama, Mongunte (bagian dari acara akikah yaitu membacakan azan, iqamat dan memberi nama, Mongakiki, yaitu acara aqiqah dengan penyembelihan hewan (kambing) pada hari mencukur rambut anak yang baru dilahirkan), Mohutingo, yaitu acara gunting rambut pada pada saat aqiqah, dan Moluna, khitan atau sunat bagi anak lakiyang sudah samapai umur 10-12 dan sudah taman mengaji.

2. Pernikahan, dengan tahapan sebagai yaitu:

a. Modolohupa (pertemuan informal) meliputi Mongilalo (peninjauan) Mohabari (meminta penjelasan), Momata U Pilootawa (meminta penjelasan ulang).

b. Motolobalango (meminang), merupakan acara peresmian hasil pembicaraan dari ketiga tahapan adat terdahulu, dilingkungan keluarga kedua belah pihak, meliputi Monga'ata Dalalo (bermusyawarah secara luas dan Motonelo (peresmian hubungan antara kedua keluarga).

c. Modutu (menghantarkan mahar)

d. Modepita Dilonggato (Mengantarkan Bahan Makanan).

e. Moponika (Akad Nikah), meliputi Mopotilantahu (mempertunangkan), Mongakaji (akad nikah), Modelo (mengantar pengantin ke rumah orang tua laki-laki.

3. Penyambutan Adat (Motombulu) yaitu acara adat sebagai bentuk tatakrama dan sopan santun dalam menghargai tamu. Tamu yang dimaksud yaitu tamu penyandang amanah Allah dalam jabatan sebagai pembesar Negara yang berkunjung di daerah ini.

4. Penobatan/Pemberian Gelar (Pohutu Momulangga) yaitu acara penobatan atau pemberian gelar adat terhadapseseorang dengan harapan dalam mengemban amanah mempertimbangkan keseimbangan antara akal dan hukum islam. Acara ini juga sarat dengan dimensi akhlak islami (Husnan, 2012: 175)

5. Pemakaman (Baya Lu Bulilo) atau yang dikenal juga dengan Pohuto Molalungo, yaitu upacara adat Gorontalo yang memadukan adat istiadat dengan ajaran agama Islam. Tahapan upacara ini yaitu

a. fase persiapan meliputi pemberitahuan, pembagian kain putih, pembuatan tanggga adat, pembuatan usungan dan penggalian kuburan dan pemberian gelar bagi orang yang dianggap berjasa.

b. Fase pemakaman yang dilaksanakan sesuai dengan ajaran Islam

c. Fase setelah pemakaman yaitu ta'ziyah yang lebih dikenal hileyia (Idham, 2012: 224-226).

Kelima upacara tersebut di atas, harus dilandaskan pada nilai-nilai adat dan tradisi yang sudah mengakar dengan bersendikan pada ajaran Islam sebagai agama resmi rakyat Gorontalo. Pada acara tradisi tersebut, sangat banyak keseniankesenian yang dipertunjukan, juga tak lepas dari bingkai falsafah Gorontalo. Di antaranya yaitu seni tari. Seni Tari di daerah Gorontalo sangat beragam hanya saja sebagian dari tari tersebut sudah langka, sebagain pula sudah berkembang dalam sebuah tari kreasi. Seni tari yang merupakan bagian tak terpisahkan dari adat dan tradisi Gorontalo secara otomatis tunduk dalam falsafah yang yang bersendikan ajaran Islam. Oleh karena itu, seni tari sebagian besar diakomodasi dengan tidak menyalahi aturan-aturan agama, baik dalam bentuk dan gerak yang jauh dari nuansa erotis, maupun busana yang mesti mengedepankan kesopanan. Secara umum seni tari di Gorontalo terbagi dalam tiga, yaitu :

a. Tari Primitif atau lebih dikenal dengan dayango.

b. Tari Klasik kalangan Istana, seperti Tidi, Longgo, 
Molape Saronde

c. Tari rakyat, seperti Danadana dan Zamrah (Bila dan Daulima, 2006: 20-21).

\section{Molapi Saronde dan Motidi dalam Tinjauan Adat Gorontalo}

Molape Saronde dan Motidi merupakan rangkaian pernikahan dalam tahapan mopotilantaho (mempertunangkan) yang dirangkaikan dengan khatam qur'an bagi pengantin perempuan pada malam hari pernikahan. Tradisi Molape Saronde merupakan warisan budaya Gorontalo yang diwariskan lewat pemangku adat dan jaringan keluarga (Djakaria, 2012: 21). Molape Saronde satu paket dengan Mopotidi. Pada kedua acara ini, dipentaskan tari Molape Saronde oleh pengantin pria yang bertujuan sebagai "Popoli" artinya kecekatan, keterampilan, ketegaran seorang laki-laki, serta Tari Tidi (biasanya Tari Tidi Lo Polopalo) oleh pengantin perempuan, yang bertujuan sebagai "mopo bilohu ayuwa" kehalusan budi dan kelembutan.

Molape Saronde berarti melemparkan selendang. Tari Molape Saronde ditarikan oleh pengantin laki-laki dan diikuti oleh remaja-remaja putera dan kerabat sang pengantin. Alat tari berupa selendang dengan warna orange, kuning emas, hijau dan ungu. Penganten laki-laki memakai busana boo takwa da'adengan tutup kepala payungo tilabatayila, sementara grup penari remaja memakai busana adat takowa kiki, memakai kopiah hitan berlilitkan kain sarung di pinggang. Tarian ini diiringi rebana turunani dangn syair lagu suluta. Tarian ini dimulai oleh seorang pemangku adat bergelar tiyamo menyuguhkan sebuah kotak di hadapan pengantin laki-laki didalamnya terdapat empat buah selendang dengan warna yang berbeda lalu ia menarikan molape saronde sebagai pembuka. Setelah menari beberapa saat, ia kemudian menyangkutkan selendang ke bahu penganti laki-laki. Peristiwa menyangkutkan inilah yang disebut sebagai "molape" yang berarti mendapat giliran kehormatan untuk menari (Djakaria, 2012: 41).

Tari Molape Sarond ebukan sekedar tarian. Ia adalah bagian dari adat upacara pernikahan dan tak bisa dilepaskan dari konteksnya tersebut. Tari ini sarat nilai-nilai agama sebagai bekal bagi sang calon pengantin. Nilai ini tereferesentasi dalamgerakan tari Saronde yaitu:

1. Keterampilan, seorang suami sebagai pemimpin dalam rumah tangga hrs memiliki keterampilan

sebagai pemimpin.

2. Kecekatan, seorang suami harus cekatan dalam mencari nafkah.

3. Ketegaran, seorang suami harus memiliki sikap tegar dalam mengarungi bahtera rumah tangga, sabar dalam menjalani kesulitan hidup (Bila dan Daulima, 2006: 68).

Tradisi Molape Saronde diyakini sudah ada sejak pemerintahan Raja Eyato, tradisi ini merupakan bagian dari paket konsep "Adati Hulo-Huloqa To Saraqa, Saraqa Hulo-Huloqa To Kuruqani” (Adat Bersendi Syara', Syara' Bersendi Alquran). Falsafah ini menyatu dalam aspek kehidupan masyarakat Gorontalo termasuk dalam ritual pernikahan. Pada masa pemerintahan kolonial Belanda, tradisi Molape Saronde dilarang untuk ditampilkan. Ini terkait dengan kebijakan Belanda yang melarang kegiatan adat yang merupakan identitas masyarakat Gorontalo termasuk membekukan Banthayo Poboide serta mengikis kewenangan raja (Husnan, 2012: 182). Molape Saronde baru kembali ramai dipentaskan pada tahun 1940-an, seiring dengan perjuangan kemerdekaan Indonesia bergolak di Gorontalo (Djakaria, 2012: 22). Kini Molape Saronde sudah menjadi ikon Gorontalo sekaligus menjadi komoditi pariwisata. Tari ini bahkan sudah dipentaskan diluar dari konteks sesungguhnya yaitu bagian dari tahapan pernikahan. Tari Saronde atau selendang (tanpa kata molape) sering dipentaskan pada event nasional maupun daerah dalam bentuk sebuah tari kreasi baru.

\section{Syair Molape Saronde}

Saronde matumulalo Tari selendang akan dimulai Ode tinelo hulalo Sebagai pancaran cahaya bulan Payu lo Hulonthalo Pola adat negeri Gorontalo Dulolo mongowuto Marilah saudara-saudaraku Huloayi motidapato Kita duduk bersama disini

$\begin{array}{ll}\text { Meyi dulolo } & \text { Hay Marilah } \\ \text { Matuduwolo } & \text { Disilahkan } \\ \text { Poo limomota mayi } & \text { Sempurnakanlah } \\ \text { Payu liyo lo Holonthalo } & \text { Pola adat Gorontalo }\end{array}$

Salendengi pulutalo Bu'adelo óalalo Poragayi poopiyohe Ungalảa hibilohe

Bulayi tombulowolo Harapu timihulolo Paragayi póolo Poo piyohe ayuwa Adati lohuwa
Selendang jemputlah Buka dan kembangkanlah Menarilah dengan baik Keluarga menyaksikan

Pengantin laki-laki dijemput Diharapkan berdiri

Untuk menari Mantapkan pribadimu Ini adat negerimu 
Bubato-bubato

Lomilohu lohulato

Mamo poo patato

Utiye tahuda liyo

Ma’apu lamiyatiya

Tidi berarti tari. Tari ini merupakan tari klasik yang sarat makna, sehingga setiap unsur berupa busana, gerakan tari, formasi tari serta syair yang dilantunkan memuat nilai-nilai moral. Oleh karena itu, tarian ini tidak boleh direkayasa dan diubah bentuknya. Mengubah unsur pada tarian Tidi berarti merubah makna kandungannya. Tarian tidi diasumsikan sudah sejak zaman pemerintahan Raja Eyato yang merumuskan falsafah "Adati Hulo-Huloqa To Saraqa, Saraqa Hulo-Huloqa To Kuruqani"(Adat bersendi Syara', Syara' Bersendi Alquran). Oleh karena itu juga, filosofi yang dikandung oleh unsur tarian tidi tak lepas juga dari falsafah tersebut. Sebagaimana yang disebutkan oleh Ny. N. Oli I, bahwa jenis tarian tidi ada tujuh; yaitu, Tidi Da'a, Tidi Lo Polopalo, Tidi Lo Tihu'o, Tidi Lo O’ayabu, Tidi Lo Tonggalo, Tidi Lo Malu'o dan Tidi Lo Bitu'o (Bila dan Daulima, 2006: 2021).

Acara Motidi (menari Tidi) di malam pernikahan didasarkan pada permintaan dari pihak laki-laki. Tidi yang ditampilkan biasanya Tidi Lo Polopalo.Polopalo dikenal sebagai alat permainan rakyat. Pada tahun 1980 menjadi alat musik berkat hasil karya Rusdin Palada. Polopalo terbuat dari sepotong bambu yang kering dengan panjang $40 \mathrm{~cm}$ (Bay dan Daulima, 2006: 61). Tarian ini diperankan oleh pengantin perempuan dengan seorang pendamping. Tidi Lo Polopalo sebagai simbol pelajaran bagi sang pengantin perempuan yang akan memasuki kehidupan rumah tangga. Alat yang digunakan yaitu Polopalo yang bermakna sebagai senjata dalam mengarungi kehidupan dan kembang yang bermakna sebagai perisai hidup (Botutihe dan Daulima, 2003: 175).

Nasihat Agama dalam gerakan Tari Tidi Lo Polopalo :

1. Memalingkan muka ke kanan/kiri, setiap tindakan harus diawali dengan pemikiran dan penelitian

2. Mendayung, siap mendampingi suami dlm mendayung rumah tangga.

3. Turun dari papan, siap dengan tantangan kehidupan di luar rumah.

4. Meletakkan tangan sejajar perut membentuk lingkaran, siap bercermin pada adat istiadat leluhur

5. Menggerakkan kedua tangan ke samping ke kanan lalu ke kiri sejajar bahu, mengutamakan sikap ramah-tamah, memperbanyak kawan.

6. Meletakkan tangan kanan di bahu dan tangan kiri di pinggang, bahu-membahu saling mendukung menuju rumah tangga bahagia, sakinah, mawaddah dan penuh kasih sayang.

7. Menangkis (keliling 4 sudut), menangkis tantangan rumah tangga dari manapun arahnya (Botutihe dan Daulima, 2003: 175-176).

\section{Syair dalam Tidi Lo Polopalo}

Popo tolimowa mayi Serahkan kemari Polopalo li bulayi Polopalo pengantin

Botiye polopalo Inilah polopalo

Dihimi po'o tohetalo Peganglah erat-erat

Bulayi Potidipio

Payinga u molito

Dila ohuto ololo

Polopalo tilingulo

Pengantin puteri menarilah Singkirkanlah rasa malu

Jangan lagi rindu

Polopalo pertahananmu

Wonu odungga la bali Jika menemukan tantangan Po'o tahangi u sabali Bertahanlah dengan sabar

Utiye nasehati

Ungala'a ihilasi

Inilah nasehat

Kerabat telah ikhlas

Modile momongu bele Berpasangan dan berumah

Po'o toheta tomele

Dila potiti mangulu tangga

Dahayiu takabulu

Perkuat pertahanan

Jangan lalai

Jaga sifat takabur

Wonu motolo ngala'a

Dila putiti uda'a

Podutolo posabali

Kalau berkeluarga

Jangan bertingkah

Bertahan dan bersabar

Dileya malo kakali

Rumah tangga akan kekal

$\begin{array}{ll}\text { Wonu moliliola } & \text { Kalau ada masalah } \\ \text { Agama u pomontolo } & \text { Agama yang melerai } \\ \text { Tidi mayi lapato } & \text { Tidi telah selesai } \\ \text { Lomilohu lo hulato } & \text { Maafkan para hadirin } \\ & \text { Menyaksikan dan menunggu. }\end{array}$

\section{Tema Wacana SyairMolapi Saronde dan Motidi}

Salah satu ciri dari sebuah teks tertulis maupun lisan yaitu kesatuan semantik. Dalam hal ini, yang dituntut dari sebuah teks yaitu tema global yang melingkupi semua unsur. Tema menunjukkan gagasan dasar dan tujuan utama sebuah teks. Dengan kata lain, tema berfungsi sebagai ikhtisar teks atau perumusan simboliknya. Lebih lanjut, dalam teksteks yang ingin meyakinkan pembaca atau pendengar, kesatuan-kesatuan teks tersebut merupakan alasanalasan yang diajukan yang disebut dengan motif 
(Pradotokusumo, 2001: 26). Dalam kaitannya dengan syair molape saronde dan motidi, tema teks tak terlepas dari sistem idiologi yang merujuk pada falsafah "Adati Hulo-Huloqa To Saraqa, Saraqa Hulo-Huloqa To Kuruqani" (Adat Bersendi Syara, Syara' Bersendi Alquran). Konsep ini sebagaimana disebutkan sebelumnya sudah bertransformasi dalam setiap upacara adat di Gorontalo termasuk tradisi Molape Saronde dan Motidi yang menjadi bagian dari upacara adat pernikahan.

Dari pembacaan syair Molape Saronde, secara khusus tema wacana pada syair yang dilantunkan yaitu penjelasan bahwa Molape Saronde sebagai bagian dari adat Masyarakat Gorontalo yang harus selalu dipelihara. Ini tergambar pada bait pada hampir seluruh bait syair khusunya pada bait pertama sebagai pembuka:

Saronde matumulalo Tari selendang akan dimulai Ode tinelo hulalo Sebagai pancaran cahaya bulan Payu lo Hulonthalo Pola adat negeri Gorontalo Dulolo mongowuto Marilah saudara-saudaraku Hulo'ayi motidapato Kita duduk bersama disini

Pada bait selanjutnya, secara khusus menjelaskan tentang adat Gorontalo yang mesti dijunjung tinggi. Idieologi ini tergambar pada sebagaian wacana syair sebagaimana dapat dilihat berikut:

$\begin{array}{ll}\text { Meyi dulolo } & \text { Hay Marilah } \\ \text { Matuduwolo } & \text { Disilahkan } \\ \text { Poo limomota mayi } & \text { Sempurnakanlah } \\ \text { Payu liyo lo } & \text { Pola adat Gorontalo } \\ \text { Holonthalo } & \end{array}$

Salendengi pulutalo Selendang jemputlah Bu'adelo óalalo Buka dan kembangkanlah Poragayi poopiyohe Menarilah dengan baik Ungala’a hibilohe Keluarga menyaksikan

Bulayi tombulowolo Pengantin laki-laki dijemput Harapu timihulolo Diharapkan berdiri

Paragayi poolo Poo piyohe ayuwa Adati lohuwa Untuk menari Mantapkan pribadimu Ini adat negerimu

Bubato-bubato Lomilohu lohulato Mamo poo patato Utiye tahuda liyo Ma’apu lamiyatiya

Para pembesar negeri Menonton dan menunggu Mengamati dengan jelas Ini adalah fatwa Maafkan kami semua

Dalam konteks masyarakat Gorontalo, adat merupakan sesuatu yang harus dijunjung tinggi dan diamalkan sepanjang tidak bertentangan dengan ajaran Islam yang bersumber dari Alquran.
Konsensus ini sudah lama berlaku sejak Raja Eyato merumuskan konsep Adati Hulo-Huloqa To Saraqa, Saraqa Hulo-Huloqa To Kuruqani (Adat Bersendi Syara', Syara' Bersendi Alquran).

Sementara tema wacana pada syair Motidiyang dilantunkan berisi:

\section{Tahan dan Sabar}

Sabar atau menahan diri dalam masyarakat Gorontalo disebut dengan jamotuqalo moingo. Sikap ini merupakan sikap tidak cepat marah dan mampu menahan diri. Ideologi sabar tergambarkan pada wacana berikut ini:

\begin{tabular}{|c|c|}
\hline Wonu odungga la bali & $\begin{array}{l}\text { Jika menemukan } \\
\text { tantangan }\end{array}$ \\
\hline Po'o tahangi u sabali & $\begin{array}{l}\text { Bertahanlah dengan } \\
\text { sabar }\end{array}$ \\
\hline Utiye nasehati & Inilah nasehat \\
\hline Ungala’a ihilasi & Kerabat telah ikhlas \\
\hline
\end{tabular}

Tahan dan sabar juga tergambar pada wacana di bawah ini:

Wonu motolo ngala'a
Dila putiti uda'a
Podutolo posabali
Dileya malo kakali

Dalam konteks Islam, agama ini mengajarkan pada penganutnya untuk selalu mampu menahan diri serta bersabar. Dalam Alquran disebutkan:

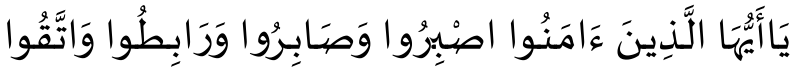

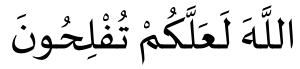

$$
\begin{aligned}
& \text { Kalau berkeluarga } \\
& \text { Jangan bertingkah } \\
& \text { Bertahan dan bersabar } \\
& \text { Rumah tangga akan } \\
& \text { kekal }
\end{aligned}
$$

"Hai orang-orang yang beriman, bersabarlah kalian dan kuatkanlah kesabaran kalian dan tetaplah bersiap siaga dan bertakwalah kepada Allah supaya kalian beruntung." (Q.S. Ali 'Imran/3: 200)

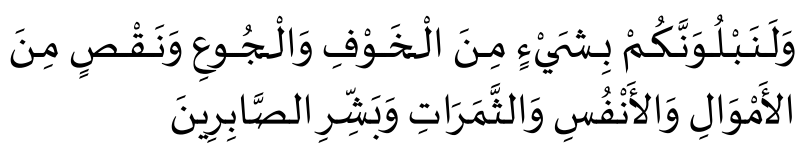

"Dan sungguh akan Kami berikan cobaan kepada kalian, dengan sedikit ketakutan, kelaparan, kekurangan harta, jiwa dan buah-buahan. Dan berikanlah berita gembira kepada orang-orang yang sabar." (Q.S. Al-Baqarah/2: 155)

Dalam konteks syair, sabar ditandai dengan ucapan poo tahangi u sabali (bertahanlah dengan sabar) dan podutolo posabali (bertahan dan bersabar). Anjuran bersabar ini merupakan 
peringatan bagi calon pengantin bahwa hidup ini penuh tantangan. Oleh karena itu diharus dihadapi dengan tenang, kuat dan sabar.

\section{Tawadhu (tidak sombong)}

Tawadhu adalah sikap merendahkan diri secara sopan santun. Tawadhu dalam dalam masyarakat Gorontalo dikenal dengan motitiwoyoto wagu motitilumboyoto. Antonim kata ini motitiwanggango wagu motitilnggati (angkuh dan congkak). Idiologi tersebut sudah menjadi bagian dari falsafah hidup masyarakat Gorontalo. Ideologi tawadhu

tereferesentasi pada wacana berikut ini:

$\begin{array}{ll}\begin{array}{l}\text { Modile momongu } \\ \text { bele }\end{array} & \begin{array}{l}\text { Berpasangan dan berumah } \\ \text { tangga }\end{array} \\ \text { Poo toheta tomele } & \text { Perkuat pertahanan } \\ \text { Dila potiti mangulu } & \text { Jangan lalai } \\ \text { Dahayiu takabulu } & \text { Jaga sifat takabur }\end{array}$

Ditinjau dari sisi ajaran Islam, tawadhu merupakan akhlak mulia yang harus dimiliki oleh setiap muslim. Allah swt berfirman dalam Alquran:

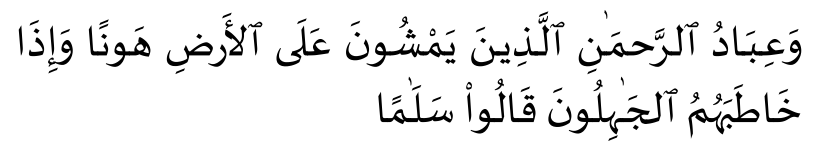
Dan hamba-hamba Tuhan yang Maha Penyayang itu (ialah) orang-orang yang berjalan di atas bumi dengan rendah hati dan apabila orang-orang jahil menyapa mereka, mereka mengucapkan katakata (yang mengandung) keselamatan. (Q.S. AlFurqan/25: 63)

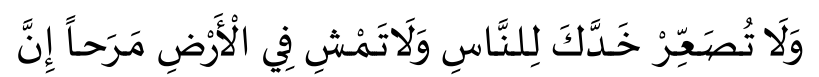

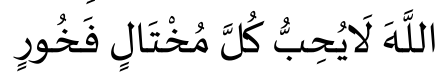

"Dan janganlah kamu memalingkan mukamu dari manusia (karena sombong) dan janganlah kamu berjalan di muka bumi dengan angkuh. Sesungguhnya Allah tidak menyukai orang-orang yang sombong lagi membanggakan diri.” (Q.S. Luqman/31: 18)

Dalam konteks wacana syair, sebelum sifat tawadhu ditandai dengan ucapan dahayiu takabulu dan didahului perintah dila potiti mangulu (jangan lalai). Pernyataan ini adalah nasehat sekaligus peringatan agar dalam menjalani kehidupan rumah tangga kelak harus mengedapankan sikap tawadhu di hadapan Tuhan dan manusia sebagai manifestasi ketakwaan. Tawadhubukan berarti seorang memiliki derajat yang rendah tetapi tawadhu memiliki nilai bahwa seorang manusia harus selalu ingat dan sadar bahwa ia diciptakan oleh Tuhan sebagai manusia yang memiliki keterbatasan sehingga membutuhkan orang lain. Oleh karena itu tidak boleh meremehkan orang. Sikap takabur sering melalaikan seseorang sehingga melampaui batas.

\section{Pegangan Hidup.}

Pegangan hidup dalam masyarakat Gorontalo sebagai orang Islam yaitu ajaran Islam bersumber dari Alquran dan Hadis. Dalam konteks ini, nasehat untuk berpegang teguh pada ajaran agama terlihat pada wacana syair berikut ini:
Wonu moliliola
Agama u pomontolo
Tidi mayi lapato
Lomilohu lo hulato
Kalau ada masalah
Agama yang melerai
Tidi telah selesai
Maafkan para hadirin
Menyaksikan dan menunggu.

Dalam Alquran disebutkan:

$$
\text { ذَلِكَ الْكِتَابُ لَا رَنْبَ فِيِْاهِ هُدَى لِلْمُتَّقَْْنَ }
$$

"Itulah Kitab (Alquran) tidak ada keraguan di dalamnya sebagai petunjuk bagi bagi orang yang bertakwa." (QS. Al-Baqarah/2: 2)

Rasulullah saw., bersabda pada sebuah hadis:"Telah aku tinggalkan untuk kalian, dua perkara yang kalian tidak akan sesat selama kalian berpegang teguh dengan keduanya kitabullah (Alquran) dan sunnah (hadis) Nabi-Nya."

Dalam konteks syair, seorang harus selalu berpegang tegung pada ajaran agama ditandai dengan ucapan wonu moliliola agama u pomontolo (kalau ada masalah agama yang melerai). Dalam menjalani kehidupan rumah tangga, seorang harus selalu berpegang teguh pada ajaran Islam yang berasal dari Alquran dan Hadis untuk mewujudkan keluarga bahagia dan penuh kasih sayang. Menyelesaikan persoalan keluarga juga harus kembali pada ajaran agama. Ideologi ini sangat sejalan dengan falsafah Gorontalo yang memegang teguh adat yang bersendikan Alquran.

\section{PENUTUP}

Kesimpulan darikajian ini yaitu: Tradisi Molape Saronde dan Motidi merupakan rangkaian upacara adat pernikahan dalam tahapan mopotilantaho (mempertunangkan) yang dirangkaikan dengan khatam qur'an bagi pengantin perempuan pada malam hari pernikahan. Pada kedua acara ini, dipentaskan Tari Molape Saronde oleh pengantin pria dan Tari Tidi (biasanya Tari Tidi Lo Polopalo) oleh pengantin perempuan. Kedua tari ini tak bisa lepas dari konteksnya tersebut. Tradisi Molape Saronde dan Motidi diyakini sudah ada sejak pemerintahan 
Raja Eyato. Walaupun sempat tenggelam pada masa kolonial Belanda, Molape Saronde kini sudah menjadi ikon Gorontalo sekaligus menjadi komoditi pariwisata. Adapun tema wacana pada syair Molape Saronde yang menjadi fokus kajian ini, secara umum berbicara tentang adat istiadat. Selanjutnya syair Molape Saronde secara khusus menggambarkan bahwa Molape Saronde adalah bagian dari adat Gorontalo dan adat itu harus dijunjung tinggi. Sementara syair Motidi tema umumnya berbicara tentang etika islami. Sedangkan tema khususnya yaitu tahan dan sabar, tawadhu serta pegangan hidup. Kedua tema umum yakni adat dan etika Islami yang berlandaskan Alquran merupakan referesentasi idiologi masyarakat Gorontalo yang memegang teguh adat yang bersendikan syara' dan syara' yang bersendikan Alquran.

Sebagai implikasi, kajian ini merekomendasikan kepada pihak terkait dalam hal ini pemerintah dan lembaga adat untuk melestarikan dan mengembankan tradisi Molape Saronde dan Motidi sebagai bagian dari adat Gorontalo. Disamping itu, diperlukan adanya kajian multidisipliner terhadap tradisi Molape Saronde dan Motidi untuk mengkaji nilai lokalitas yang lebih dalam lagi sebagai warisan budaya tak benda bagi generasi penerus.

\section{UCAPAN TERIMA KASIH}

Terima kasih kepada seluruh pihak yang turut membantu terlaksananya penelitian ini mulai dari awal sampai akhir. Terima kasih yang sedalamdalamnya kepada Dr. Hamzah, MA sebagai Kepala Balai Litbang Agama Makassar yang menugaskan peneliti sehingga penelitian bisa terlaksana. Ucapan terima kasih juga kepada Bapak Idham sebagai Kordinar Bidang Lektur sekaligus Kordinator penelitian ini atas berbagai arahan sehingga penelitian terlaksana dengan baik. Demikian pula terima kasih pada Bapak Medi Botutihe, Mantan Walikota Gorontalo, AW. Lihu sebagai Baate Limboto, DK Usman Baate Gorontalo, Yamin Husain Kepala Sanggar Seni Tapa, Muhammad Ichsan, Kasi Pelestarian Seni Tradisional Dinas Pendidikan dan Kebudayaan Provinsi Gorontalo, serta pihak-pihak yang terlibat langsung dalam tahap pengumpulan data penelitian.

\section{DAFTAR PUSTAKA}

Bay, Suwardi dan Farha Dualima. 2006. Mengenal Alat Musik Tradisional Daerah Gorontalo. Limboto:
Forum Suara Perempuam LSM Mbu'i Bungale.

Bila, Reiners dan Farha Daulima. 2006. Mengenal Tarian Daerah dan Klasik Gorontalo. Limboto: Forum Suara Perempuan LSM Mbu'i Bungale.

Botutihe, Medi dan Farha Dualima. 2003. Tata Upacara Adat Gorontalo. Gorontalo: Pemerintah Daerah Gorontalo.

Daulima, Farha. 2003. Tatacara Adat Perkawinan. (Pada Massyarakat Adat Suku Gorontalo). Limboto: Forum Suara Perempuan LSM Mbu’i Bungale. 2006. Ragam Upacara Tradisonal Daerah Gorontalo. Limboto: Forum Suara Perempuam LSM Mbu'i Bungale.

Djakaria, Salmin; et. al. 2012. Molape Saronde: Warisan Budaya Tak benda dalam Adat Perkawinan Gorontalo. Manado: Kementerian Pendidikan dan Kebudayaan Balai Pelestarian Nilai Budaya.

Eriyanto. 2011. Analisis Wacana: Pengantar Analisis Teks Media. Yogyakarta: LKIS Group.

Hasanuddin dan Basri Amin. 2012. Gorontalo Dalam Dinamika Sejarah Masa Kolonial. Yogyakarta: Ombak.

Husnan, Muh. Ihsan. "Pohutu Momulanga: Gelar Adat di Gorontalo" dalam Jurnal Al-Ulum, Volume 12 Nomor 1 Juni Tahun 2012.

Idham. "Pohutu Molalungo: Sinergitas Adat dan Syariat Dalam Penyelenggaraan Acara Adat Pemakaman di Pohala’a Gorontalo Indonesia" dalam Jurnal AlQalam, Volume 17 Nomor 2 Juli-Desember Tahun 2011.

Kanwil Kementerian Agama Provinsi Gorontalo. Profil Kanwil Kementerian Agama Provinsi Gorontalo 2013.

Polontalo, Ibrahim. Adat Bersendikan Syarak dan Syarak Bersendikan Kitabullah Sebagai Dasar Pengembangan Budaya dan Pelaksanaan Islam di Gorontalodalam"Membumikan Islam: Seminar Nasional Pengembangan Kebudayaan Islam Kawasan Timur Indonesia tanggal 20-21 September 2003.

Pradotokusumo, Partini Sardjono. 2001. Pengkajian Sastra. Bandung: Wacana.

Tuloli, Nani. 2003. "Sastra Lisan Gorontalo dalam Konteks Kebudayaan Islam" dalam Membumikan Islam: Seminar Nasional Pengembangan Kebudayaan Islam Kawasan Timur Indonesia tanggal 20-21 September.

Umar, Fatmah AR. Tth. Ideology Tuja'i: Analisis Wacana Kritis. Gorontalo: Ideas Publishing. 